\title{
Foreign Direct Investment and Economic Growth in the European Union
}

\author{
Argiro Moudatsou \\ Technological Educational Institute of Crete
}

\begin{abstract}
This paper contains an empirical assessment of the growth effects of foreign direct investment (FDI) in European Union (EU) countries, when controlling for other growth determinants. Using data over the period 1980-1996, we obtained estimates of the growth effects of FDI for each country in isolation and by pooling the data for the whole Union. Country-specific estimates suggest that growth determinants vary across EU members and that only past FDI inflows have a significant effect on growth. Interestingly, when data are pooled, the empirical results show that FDI has a positive effect on the growth rate of EU economies both directly and indirectly (through trade reinforcement). Also, unlike previous empirical findings concerning developing economies, we obtained evidence that the growth effect of FDI is not conditional upon the level of human capital in developed host countries.
\end{abstract}

- JEL Classifications: F21, F23

- Key words: Foreign direct investment, Economic growth

\section{Introduction}

Economic growth is a complex phenomenon which is affected by economic, cultural and institutional factors. As such, the lines of causation between growth and various economic factors are frequently bi-directional in nature. Furthermore, the various factors that have been proposed to explain growth are themselves

*Corresponding address: Professor Argiro Moudatsou, School of Management and Economics, Technological Educational Institute of Crete, 71500 Heraklion, Crete, Greece. Telephone +30 2810 342136, Fax +30 2810227189 Email: amoudats@ebeh.gr (C2003-Center for International Economics, Sejong Institution, All Rights Reserved. 
interrelated. These causality problems plague all studies attempting to empirically analyze whether and to what extent a particular factor or group of factors affect growth.

Similar considerations apply to empirical studies that attempt to quantify the impact of FDI on growth. These considerations manifest themselves and operate through many standard channels: firstly, FDI inflows could affect capital formation because they are a source of financing, and capital formation is one of the prime determinants of economic growth. Secondly, inward FDI may increase a host country's productivity and change its comparative advantage. If productivity growth were export biased, then FDI would affect both growth and exports. Thirdly, a host country's institutional characteristics - such as its legal system, enforcement of property rights etc. - could influence simultaneously the extent of FDI inflows and capital formation in that country.

Empirical studies on the determinants of economic growth have followed two avenues of analysis. For the most part, they examine the determinants of growth over a period of time using available time-series data on per-capita GNP, capital accumulation, FDI inflows, openness to trade, human capital etc. However, one problem with the interpretation of the results of these studies is the difficulty of determining the direction of causation. For example, a typical question might be whether an economy is growing more rapidly than another because the level of capital formation is higher or is the rate of capital formation higher because the economy is growing faster? An alternative avenue of research is to break a long period into sub periods so that the timing of growth and its presumed determinants reveals something about the direction of causation.

Several studies of long-term growth have incorporated FDI into their sets of explanatory variables tended to find that rapid growth and high ratios of FDI to GDP have gone together. For example, Blomstoerm, Lipsey, and Zejan, (1994) report a significant correlation between inflows of FDI as a percentage to GDP and the growth per capita GDP across all developed countries for the period 19601985. They suggest that although the gap in technology and productivity between foreign-owned firms and domestically-owned ones is larger in poorer countries than in richer ones, that does not necessarily mean that the poorer countries gain the most from inward FDI. The study argues that "the least developed countries may learn little from multinationals, because local firms are too far behind in their technological levels to be either imitators or suppliers to multinationals". The authors found empirical support for this supposition, in the sense that inflows of FDI were significant determinants of growth for the upper half of the distribution 
of countries, when ranked by per capita income, but not for the lower half. Also the paper by Borenstein (1998) highlights the role of FDI as an important vehicle of economic growth only in the case that there is sufficient absorptive capability in the host economy. This capability is dependent on the achievement of a minimum threshold of human capital.

A similar conclusion was reached in a study investigating growth per capita GDP for 69 developing countries from 1970 to 1989 (Borenstein, De Gregorio and Lee, 1995). The FDI variable in this study was measured by the inflow of FDI originating in OECD countries. FDI itself had a marginally significant positive influence on growth, but an interaction term bertween FDI and educational attainment turned out to be a stronger and have more consistent influence on growth. The higher the level of education, the greater is the gain in growth from a given inflow of FDI.

An interaction between FDI and education was also found in a paper on FDI in China which concluded that education becomes even more effective when it is associated with knowledge.... the interaction between school enrolment rates and foreign investment is significantly positive, suggesting mutual reinforcement between domestic human capital and foreign knowledge that accompanies the investment. However, the coefficient on foreign investment becomes negative when the interaction term is introduced, implying that much of the power of foreign knowledge may come through the local base of human capital (Mody and Wang, 1997).

Borenstein, De Gregorio and Lee (1995) studied also for those 69 countries the growth effects of inward FDI through its impact on domestic capital formation. According to the authors, FDI encourages capital formation by domestic firms so that a one-dollar increase in the net inflow of FDI is associated with an increase in total investment in the host economy of more than one dollar. This does not, of course, mean that the possibility of FDI-induced crowding out of local capital formation can be ruled out.

Also, Borenstein (1998) noted that the coefficient of FDI by itself is not statistically significant. Since the adoption of new technology requires an educated labor force the author takes into account a complementary relationship between FDI and schooling by including an interaction term. A positive sign of this term supports the notion that FDI is able to generate detectable beneficial impact on economic growth only for those countries in which the existing stock of human capital has reached a certain minimum threshold level.

On the other hand, the insignificancy of the coefficient of that term implies that 
the effect of FDI is not necessarily conditional upon a minimum threshold of human capital. And this finding is complement to the results of Borenstein and Campos-Kinoshita (2002). In that case, the host country should be above the threshold of human capital necessary to adopt the advanced technology transferred by FDI.

Focusing solely on OECD countries, de Mello (1999) finds that FDI is growthenhancing only for countries in which domestic and foreign capital are complements. Yet Lipsey (2000) reports that there is little evidence of the impact of FDI on domestic capital formation

Several cross-section studies have included a measure of FDI as a potential source of growth (see Blomstroem, Lipsey and Zejan, 1994 and Borenstein, De Gregorio and Lee, 1995 among others). However, some of the variables identified in these studies as growth determinants are typically correlated with FDI. For example, relatively robust relations were found between investment ratios (investment/GDP) and growth and between investment ratios and trade ratios. But both of these ratios could be affected by FDI flows, and thus, indirectly form a channel for an effect of FDI on growth. Another example refers to the effects on growth of knowledge spillovers. FDI is also a plausible vehicle for these knowledge spillovers, by itself through $R \& D$ and through its relation to the intensity of trade.

There is a great deal of evidence that foreign-owned firms in most countries trade more with their parent countries but also trade more in general, than locallyowned firms. A summary of the evidence suggests that MNEs or their affiliates generally enjoy a larger share of home and host country exports and imports than they do of output.... this is partly explained by their being concentrated in tradeintensive sectors, and partly because their trading propensity in any given sector tends to be greater than that of national or indigenous firms ${ }^{1}$.

It is likely therefore that high foreign ownership ratios, or large inflow of FDI, will increase the importance of trade for a host country, thus affecting the growth indirectly.

Campos and Kinoshita (2002) in a study of the impact of FDI on economic growth in 25 Central and Eastern European and former Soviet Union transition economies between 1990-1998 found that FDI has a positive effect on economic growth. M. Bengoa Calvo and B Sanchez-Robles (2002) in their study exploring empirically the interplay between Economic Freedom, growth and FDI , using panel data analysis on a sample of 18 Latin America countries over the period 1970-1999 found a positive effect of FDI on their growth. Also they point out to

\footnotetext{
${ }^{1}$ Dunning, 1993
} 
the need of certain level of human capital

In another UNCTAD study, presented in World Investment Report 1999, an effort was made to assess the impact of FDI on growth when other growthpromoting factors were taken into account. Using regression analysis the study included as growth determinants (measured by the change in real per capita income), the investment expenditure as a share of GDP (measured in real terms at each periodís current national prices), the inward flow of FDI as a per cent of nominal GDP, past growth in real per capita GDP, the level of schooling at the beginning of the period and changes in the labor force participation rate. The sample covered over 100 developing countries and five periods between 1970-1995.

One difficulty in interpreting most growth regression equations was that the dependent and independent variables interacted in both directions: High growth rates induced high investment rates and high investment rates induced high growth rates. To reduce such ambiguities (although without completely eliminating them) those independent variables that were most clearly subject to this two-way interaction (like FDI, and investment) were introduced in lagged form. Since several independent variables were strongly correlated over time, the time series properties of these relationships were examined. This was achieved by including country-specific dummy variables in the equations.

The results in the above study of UNCTAD in general showed the following: the ratio of FDI inflow to GDP in a period has consistently the largest positive influence on subsequent growth in per capita real income, although it is rarely statistically significant except when combined with the level of schooling. In the combined cross-section and time-series pooled equations, several other factors contribute to more rapid growth. They include past growth rates, past investment ratios and increases in participation rate. In the pooled equations, when countrydummy variables introduced to eliminate the influence of long-term cross-country differences in growth and other variables, past growth and past investment ratios did not appear any more as significant influences on growth. Their positive influence was absorbed by the country dummy variables. When the widest set of variables was included the only ones that appeared to increase the rate of growth were FDI inflow combined with the level of schooling in terms of magnitude and statistical significance. The effect of past FDI inflows on the rate of growth remained elusive, partly because FDI is intertwined with investment ratios and trade ratios. What is fairly established, regardless of causation, is that high growth rates and large inflows of FDI go together. In other words, FDI targets countries 
with growing markets. While the importance of multinational companies has been growing rapidly and has come to assume an important role in the globalization process, its quantitative and qualitative significance differs across countries. UNCTAD $^{2}$ data on regional distribution of FDI inflows show that the developing countries receive a smaller proportion of FDI compared to advanced countries.

The share of developed ${ }^{3}$ countries in FDI inflows increased from $63.4 \%$ in 1995 to $71.5 \%$ in 1998 while for the developing ones the FDI share decreased from $32.3 \%$ to $25.8 \%{ }^{4}$. Among developed countries, the European Union accounts for the largest share of FDI inflows (this share increased from $35.1 \%$ in 1995 to $35.7 \%$ in 1998). This means that FDI flows into the EU are significant and that they should play a very important role for the economies of its member countries (even though the FDI as percentage of GDP of EU countries is too low, Table 1). The fact that all of the EU countries (with few exceptions) are at the same time receivers and exporters of FDI (in Table 2 we can see that the greatest receivers of FDI are, in descending order, Belgium/Luxemburg, the Netherlands, Sweden, UK, Spain, Portugal Ireland, while the greatest exporters of FDI are Sweden, UK, the Netherlands, Belgium/Luxemburg, France and Germany) raises questions about the role of FDI on their growth level. This is enhanced by the fact that the share of FDI as percentage of fixed capital formation has been rising over the period 19871997 (Table 3).

Most of the work on this field (FDI-growth) has been done for developing economies. On the other hand my work focuses on the FDI-growth results when developed countries are under consideration.

The results showed that there are some differences regarding the effects of FDI on growth when the host countries belong to the developed group.

The paper is organized as follows. The theoretical background is outlined in section 2. The empirical methodology is discussed in the third section and the empirical results, based on annual data covering the period 1980-1996, are reported in section 4 . The final section includes a summary and conclusions.

\footnotetext{
${ }^{2}$ UNCTAD: United Nations Conference on Trade and Development

${ }^{3}$ Developed countries: European Union, Other Western Europe, United States, Japan, Other developed countries

${ }^{4}$ World Investment Report 1999, UN
} 
Table 1. Pooled equation (all countries) with dummy variables.

Dependent variable: GROWTH Included observations after adjusting points: 237

\begin{tabular}{|c|c|c|c|}
\hline Variable & Coefficient & t-stat (at a =0.05) & Prob \\
\hline Constant & 3.608 & 1.914 & 0.056 \\
\hline $\mathrm{FDI}_{\mathrm{t}-1}$ & -104.908 & -1.702 & 0.090 \\
\hline FDI & 54.956 & 3.16 & 0.001 \\
\hline TRADE & 3.581 & 1.941 & 0.053 \\
\hline TRADE $_{\mathrm{t}-1}$ & 1.723 & 2.419 & 0.016 \\
\hline CAPITAL $_{\mathrm{t}-1}$ & -0.612 & -7.340 & 0.000 \\
\hline CAPITAL & 0.476 & 0.072 & 0.000 \\
\hline EDU & -0.745 & 0.336 & -2.215 \\
\hline FDI*EDU & 27.428 & 1.239 & 0.216 \\
\hline Dbelgium/Luxemburg & -11.739 & -2.188 & 0.029 \\
\hline DDenmark & -0.712 & -0.897 & 0.370 \\
\hline Dgermany & 0.187 & 0.238 & 0.811 \\
\hline Dgreece & -0.369 & -0.532 & 0.594 \\
\hline Dspain & 1.499 & 1.901 & 0.058 \\
\hline Dfrance & 0.364 & 0.489 & 0.625 \\
\hline Direland & -1.072 & -0.820 & 0.413 \\
\hline Ditaly & 0.630 & 0.760 & 0.407 \\
\hline Dnetherlands & -2.928 & -2.125 & 0.034 \\
\hline Daustria & -0.745 & -0.827 & 0.409 \\
\hline Dportugal & 0.946 & 1.038 & 0.300 \\
\hline Dfinland & 0.895 & 0.999 & 0.318 \\
\hline Dsweden & -1.478 & -2.037 & 0.042 \\
\hline R-squared $=0.51$ & \multicolumn{3}{|c|}{ S.E of Regression $=1.824$} \\
\hline Adjusted R-squared $=0.35$ & \multicolumn{3}{|c|}{ F-statistic $=10.728$} \\
\hline $\mathrm{D}-\mathrm{W}$ statistic $=1.66$ & \multicolumn{3}{|c|}{ Prob $($ F-statistic $)=0.000$} \\
\hline
\end{tabular}

Table 2. Pooled equation without dummies.

Dependent variable: GROWTH. Included observa-tions after adjusting points: 237

\begin{tabular}{lccc}
\hline \multicolumn{1}{c}{ Variable } & Coefficient & t-Statistic(at a=0.05) & Prob. \\
\hline Constant & 3.709 & 2.822 & 0.005 \\
FDI $_{\mathrm{t}-1}$ & -87.442 & -1.473 & 0.141 \\
FDI & 50.029 & 2.868 & 0.004 \\
TRADE $_{\mathrm{t}-1}$ & -0.354 & -0.480 & 0.631 \\
TRADE & 1.745 & 2.374 & 0.018 \\
CAPITAL & -0.593 & -7.782 & 0.000 \\
CAPITAL & 0.536 & 7.364 & 0.000 \\
EDU & -0.537 & -1.683 & 0.093 \\
FDI*EDU & 20.988 & 0.976 & 0.329 \\
\hline
\end{tabular}

( $\mathrm{t}$-test values, in brackets)

$\mathrm{R}$-squared $=0.42$

Adjusted R-squared $=0.40$

$\mathrm{D}-\mathrm{W}$ statistic $=1.42$
S.E of Regression $=1.918$

F-statistic $=21.28$

Prob $($ F-statistic $)=0.000$ 
Table 3. FDI as percentage to GDP

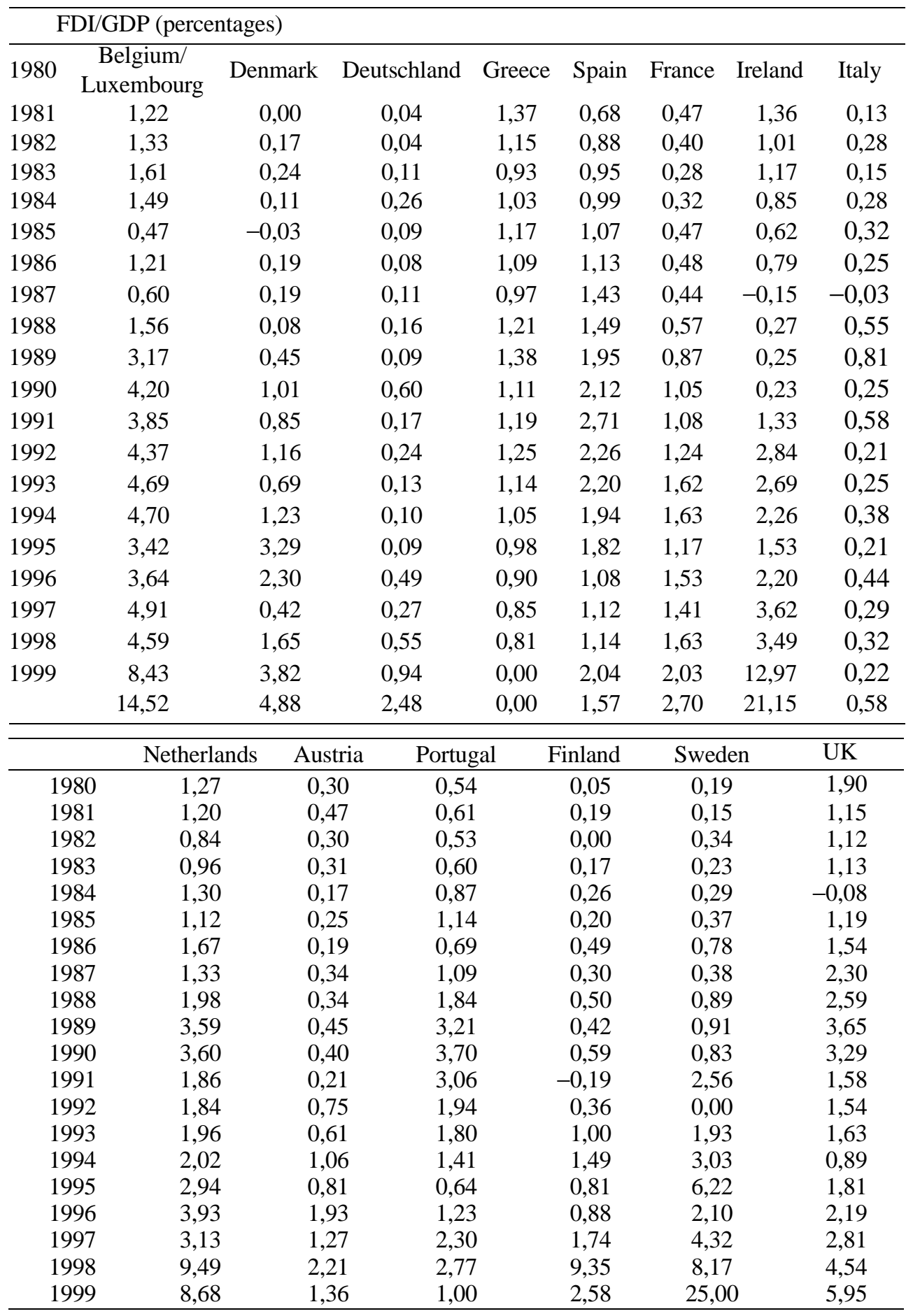

Elaborated data, Source European Economy 2001 
Table 4. Inward and outward FDI flows as percentages of gross fixed capital formation

\begin{tabular}{|c|c|c|c|c|c|c|}
\hline Region/economy & $\begin{array}{c}1987-1992 \\
\text { annual average }\end{array}$ & 1993 & 1994 & 1995 & 1996 & 1997 \\
\hline \multicolumn{7}{|l|}{ World } \\
\hline Inward & 4.1 & 4.3 & 4.6 & 5.4 & 5.8 & 7.7 \\
\hline outward & 4.7 & 5.0 & 5.3 & 6.0 & 6.3 & 8.0 \\
\hline \multicolumn{7}{|l|}{ Developed countries } \\
\hline Inward & 4.2 & 3.6 & 3.7 & 4.7 & 4.8 & 6.6 \\
\hline outward & 5.7 & 5.6 & 6.1 & 7.0 & 7.3 & 9.7 \\
\hline \multicolumn{7}{|l|}{ Western Europe } \\
\hline Inward & 5.7 & 5.7 & 5.8 & 7.1 & 6.8 & 8.6 \\
\hline outward & 8.3 & 7.9 & 9.3 & 10.3 & 12.0 & 15.4 \\
\hline \multicolumn{7}{|l|}{ European Union } \\
\hline Inward & 5.8 & 5.9 & 5.6 & 7.2 & 6.8 & 8.5 \\
\hline outward & 8.3 & 7.6 & 8.9 & 10.0 & 11.4 & 14.8 \\
\hline \\
\hline Inward & 2.0 & 2.9 & 4.8 & 3.5 & 8.1 & 4.8 \\
\hline Outward & & 3.0 & 2.9 & 2.1 & 3.5 & 3.9 \\
\hline \multicolumn{7}{|l|}{ Belgium / } \\
\hline Luxemburg Inward & 20.3 & 26.1 & 19.4 & 20.7 & 27.9 & 26.7 \\
\hline outward & 17.4 & 11.9 & 3.1 & 22.4 & 16.0 & 16.6 \\
\hline \multicolumn{7}{|l|}{ Denmark } \\
\hline Inward & 3.7 & 6.8 & 18.9 & 12.4 & 2.2 & 8.3 \\
\hline outward & 6.2 & 5.4 & 15.7 & 8.9 & 7.1 & 12.4 \\
\hline \multicolumn{7}{|l|}{ Finland } \\
\hline Inward & 1.4 & 6.9 & 10.5 & 5.4 & 5.5 & 10.5 \\
\hline outward & 5.3 & 11.2 & 30.7 & 7.7 & 17.9 & 26.2 \\
\hline \multicolumn{7}{|l|}{ France } \\
\hline Inward & 5.3 & 7.1 & 6.5 & 8.6 & 8.2 & 9.7 \\
\hline outward & 9.9 & 8.5 & 10.2 & 5.7 & 11.3 & 15.0 \\
\hline \multicolumn{7}{|l|}{ Germany } \\
\hline Inward & 0.8 & - & 1.6 & 2.3 & 1.1 & 2.3 \\
\hline outward & 5.5 & 4.1 & 4.2 & 7.5 & 10.9 & 9.5 \\
\hline \multicolumn{7}{|l|}{ Greece } \\
\hline Inward & 5.8 & 5.2 & 5.3 & 4.8 & 4.4 & 4.0 \\
\hline outward & 0.1 & - & - & -0.5 & 0.3 & - \\
\hline \multicolumn{7}{|l|}{ Ireland } \\
\hline Inward & 8.9 & 14.9 & 9.6 & 13.4 & 20.6 & 19.0 \\
\hline outward & 5.5 & 2.9 & 5.0 & 7.6 & 5.7 & 7.0 \\
\hline \multicolumn{7}{|l|}{ Italy } \\
\hline Inward & 2.2 & 2.6 & 1.3 & 2.6 & 1.7 & 1.9 \\
\hline outward & 2.5 & 5.6 & 3.3 & 3.7 & 2.9 & 5.4 \\
\hline
\end{tabular}


Table 4. Continued

\begin{tabular}{ccccccc}
\hline Region/economy & $\begin{array}{c}1987-1992 \\
\text { annual average }\end{array}$ & 1993 & 1994 & 1995 & 1996 & 1997 \\
\hline $\begin{array}{c}\text { Netherlands Inward } \\
\text { outward }\end{array}$ & 13.1 & 14.2 & 11.4 & 15.6 & 18.9 & 12.9 \\
Portugal & 22.6 & 20.2 & 27.5 & 25.8 & 40.5 & 29.4 \\
Inward & & & & & & \\
outward & 1.4 & 0.7 & 1.4 & 2.8 & 3.0 & 7.5 \\
Spain & & & & & & \\
Inward & 9.9 & 10.1 & 9.8 & 5.9 & 5.7 & 5.9 \\
outward & 2.2 & 3.2 & 4.1 & 3.6 & 4.7 & 11.5 \\
Sweden & & & & & & \\
Inward & 5.0 & 14.5 & 23.4 & 42.9 & 13.6 & 35.0 \\
outward & 18.0 & 5.2 & 24.7 & 33.3 & 12.5 & 40.6 \\
UK & 13.5 & 10.9 & 6.1 & 11.9 & 14.5 & 18.6 \\
Inward & 16.1 & 19.0 & 22.2 & 25.9 & 19.7 & 32.0 \\
outward & & & & & & \\
OTHER WESTERN & & 2.5 & 8.2 & 6.2 & 6.8 & 10.1 \\
EUROPE & 3.5 & 12.5 & 15.5 & 15.6 & 23.4 & 25.2 \\
Inward & 9.0 & & & & &
\end{tabular}

\section{How FDI Affects Output: A Theoretical Analysis}

The next step of the analysis is to identify the possible channels through which FDI affects a host country and its economic growth. FDI comprises a bundle of assets, some proprietary to the investors and some not. The proprietary assets $\tilde{n}$ technology, brand recognition, and managerial techniques $\tilde{n}$ are responsible for what the literature calls the "ownership advantages" of MNEs. These advantages give MNEs a competitive edge over local firms and allow the former to overcome the transaction costs of operating across national boundaries. Non-proprietary assets $\tilde{n}$ finance, capital goods, intermediate inputs and the like $\tilde{n}$ can be obtained from the market at least in part. Proprietary assets can only be obtained from the firms that create them. MNEs are naturally reluctant to sell their most valuable assets to unrelated firms ñ potential competitors $\tilde{n}$ or to third parties. The following paragraphs briefly describe the asset categories associated with FDI inflows.

Capital (Impact on investment): FDI brings in host countries financial resources, investing in long-term projects. As distinct from other sources of capital such bank loans, bonds or even portfolio equity capital (which represent external 
forms of foreign saving that are used for investment by local firms), FDI is the only source that internalizes foreign savings, that is, the firms which bring these savings, undertake investment. MNEs can thus affect investment in host countries directly through their own investment activities, and indirectly by inducing more investment undertaken by host-country firms. It should be noted though, that FDI flows underestimate total investment of foreign affiliates in host countries.

The difference between the two measures (foreign affiliate investment expenditure and FDI) could be attributed to two factors. Firstly, foreign affiliates can finance their investment expenditures from a variety of sources. For example, borrowing in the host-country capital market, or in the global financial market can finance these expenditures Secondly, financial flows for Mergers and Acquisitions (M\&A) represent change of ownership in existing assets and therefore do not contribute to the host country capital formation at the moment of entry, although they may lead to investment in the future through subsequent investment.

Does FDI crowd out or crowd in domestic investment? Crowding out total investment in host country may occur if MNEs borrow in host country under conditions of scarcity and hence increase domestic interest rates, making thus borrowing unfavorable to local firms. Crowding in takes place when investment by foreign affiliates stimulates new investment in downstream or upstream markets in the host country, or increases the efficiency of financial intermediation. The existence of backward and forward linkages to local companies is a key consideration for determining the local impact of FDI on capital formation.

Technology: FDI is an important vehicle for the transfer of technology, contributing relatively more to economic growth than domestic investment. However, the higher productivity of FDI materializes only when the host country has a minimum threshold stock of human capital. Thus FDI contributes to economic growth only when the host country has a sufficiently high level of absorptive capability that facilitates the transfer of the advanced technology. Technology diffusion (transmission of ideas and new technology) plays a central role in the process of economic development.

Market access: FDI through MNEs can provide access to export markets offering thus benefits in terms of realization of scale economies, competitive stimulus, employment, skill upgrading and management techniques, etc.

Consequently, there are many channels through which FDI affects economic growth: through technology transfer - by increasing a host country's productivity and exports - and through trade expansion. The latter happens when MNEs 
concentrate in trade-intensive sectors. In addition, FDI could affect capital formation and, consequently, growth, since FDI inflows are a source of financing.

The above discussion establishes that there are many channels through which FDI affects growth. Inward FDI may increase a host country's productivity and exports and in turn, productivity growth may indirectly affect exports. Another channel through which the FDI affects growth is the increase in host country's trade. There is a great deal of evidence that foreign-owned firms (MNEs) trade more in general (with their parent-companies and others) than the locally owned firms. MNEs or their affiliates generally enjoy larger share of home and host country imports and exports than they do of output; this is partly explained because they are concentrated in trade-intensive sectors and partly because their trading propensity in any given sector tends to be greater than that of indigenous firms. It is likely therefore, that high shares of foreign ownership, or large inflows of FDI would increase the importance of trade, thus affecting growth indirectly. Also, a host country's institutional characteristics, such as legal system, enforcement of property rights and the extent of bureaucratic corruption, that have been suggested as explanations for different growth rates, are likely to influence the extent of FDI and capital formation.

The above views find support in basic textbooks on the theory of FDI and multinationals (Lall, Caves, Dunning, Neil Hood, Stefen Young, a.o.). Although these views are considered standard in the literature about growth and FDI, we add below some more evidence in support of the same.

In Solow-type theoretical growth models, FDI is traditionally conceived as an addition to the capital stock of the host economy. In this view, there are no substantial differences between domestic and foreign capital. More importantly, the impact of FDI on growth is similar to that of domestic capital. With diminishing returns to capital, FDI has no permanent impact on the growth rate. FDI will have a short-run impact on growth, however, which depends on the transitional dynamics to the steady-state growth path. ${ }^{5}$

In endogenous growth models, the potential role of FDI is greater. There are a number of channels through which FDI permanently affects the growth rate. One way to think about these effects is to specify how FDI affects each argument in the production function. FDI can affect output by increasing the stock of capital (as

\footnotetext{
${ }^{5}$ For surveys of the literature on economic growth see Barro and Sala-I-Martin(1995) and Aghion and Howitt(1998) For surveys of the methodology and empirical evidence, see Temple(1999) and Durrlauf and (1999) Quah
} 
has already been mentioned above). However, this impact is likely to be small under the assumption of perfect substitutability. Although the empirical evidence on this matter is mixed (Hanson 2001), if foreign and domestic capital are complements the final impact of FDI on aggregate output will be larger as a result of these externalities. Further, if foreign capital is treated differently from domestic capital, say, by way of expanding the variety intermediate goods and capital equipment, FDI can raise productivity in the host country (Borenstein et al. 1998)

Considerations, which affect a MNE in choosing a country for its operations, depend on the level of economic development. Generally speaking, when a MNE decides to establish a subsidiary in a developed country, it aims to access its large and developed market, while by investing in a less developed country it tries to take advantage of the countyís low-costs, or to access real resources.

So the links of FDI and growth seem to be different for countries of different stage of development. Besides the development impact of FDI depends on the dynamics of the transfer of the technology and skills by MNEs: how much upgrading of local capabilities takes place over time, how far local linkages deepen, and how closely affiliates integrate themselves in the local market

The European-Union countries belong to the developed group even though not all of them have the same level of development. So we expect that the growth of those countries will be affected positively by FDI since the type of investment in those countries is capital-intensive.

The group of countries that were examined includes 15 European Union countries listed as 14 because in official data sets Belgium and Luxemburg are treated as a single country for statistical purposes.

\section{Empirical Methodology}

\section{A. Methodology}

In order to assess the impact of FDI on the growth of EU economies, when other growth variables are taken into account, the method of regression analysis was used on annual time series data for the variables under consideration. Each country was examined separately and then all together in a pooled equation. So, each country's data cover periods of different length extending from 18 to 27 years, while for the pooled data the equation covered a period of 16 years (1980- 
1996) for 14 countries (a total of 237 observations).

The full version of the empirical model is given by the following function $\mathrm{GR}_{\mathrm{t}}=\beta \mathrm{o}+\beta_{1} \mathrm{CAP}_{\mathrm{t}}+\beta_{2} \mathrm{CAP}_{\mathrm{t}-1+1} \beta_{3} \mathrm{FDI},+\beta_{4} \mathrm{FDI}_{\mathrm{t}-1}+\beta_{5} \mathrm{TRADE}+\beta_{6} \mathrm{TRADE}_{\mathrm{t}-1}+\beta_{7} \mathrm{EDU}$ $+\beta_{8} \mathrm{FDI} * \mathrm{EDU}+\mathrm{u}_{\mathrm{t}}$

\section{B. Variables}

\section{Dependent Variable}

$\mathrm{GR}_{\mathrm{t}}=$ rate of growth of current period (gross domestic product at 1995 market prices, annual percentage rate).

\section{Independent variables}

$F D I_{t}=$ Foreign Direct Investment Inflows of current period (percentage to GDP measured in current prices).

$F D I_{t-1}=$ past inflows of FDI.

$C A P_{t}$ and $C A P_{t-l}=$ current and past gross fixed capital formation (current prices, as a percentage to GDP).

TRADE $=$ imports+exports (of goods and services at current prices) / GDP (at market prices).

$E D U=$ percentage of tertiary education to whole education (for each country).

$F D I E D U=$ interaction of $F D I$ and education $(F D I * E D U)$

\section{The Results}

The variables that were subjected to two-way interaction were introduced in lagged form. Since the variables used were likely to be interrelated, we first examined these relationships. One way to do this is to test the time series characteristics of the plausible variables. So, in the Granger-Sims causality framework (Granger 1969, Sims 1972) we asked whether FDI inflows are themselves influenced by contemporary or past growth rates and past FDI inflows. The results showed that current FDI inflows were influenced by past FDI inflows for all countries except Greece and Italy.

Next, for each separate country were estimated 7 different model specifications examining the different variablesí influence on growth. Summarizing the results, we could say that FDI past inflows seem to affect the economies of the most of them. We ran the estimation for each country by adding one by one the explanatory variables (that is, trade ratios, capital formation, education, and the 
interacting variable FDI*EDU) and controlling for colinearity.

The general conclusion is that the factors that affect growth differ across countries and this could be justified by differences in their growth levels. The results of the estimations of the regressions for the particular countries are available on request.

The problem with the separate regressions was that there were few observations available for each country and it is possible that we couldnít get robust results

In order to overcome the problem with the few observations we pooled the data for all countries. This was done by using data on the same variables for the same 16-year period (1980-1996). In this case the dependent variable was again economic growth. Moreover, since some of the possible variables were strongly correlated over time, the time series aspects of these relationships were also examined. This was done by including 14 country dummy-variables in the model. The equation with country dummy-variables excludes the influence of average (over period) differences among countries and reflects only changes within each country $^{6}$

The results, Table 1, indicate that growth depends positively on current FDI inflows and current and past trade ratios [for similar results see, BlomstroemLipsey-Zejan (1994), Borenstein, De Gregorio and Lee (1995), Campos and Kinoshita (2000), Bengoa and Sanchez (2002)] and it depends negatively on the education level and past investment ratios. The interaction variable FDI*EDU, does not affect growth significantly. These last findings are quite different from those of other studies. For example Borenstein, De Gregorio and Lee (1995) in a study of 69 developing countries found that an interaction term between FDI and educational attainment turned out to be a stronger and more consistent influence on growth. Similar results were reported by Borenstein (1998).

A positive sign of term FDI*EDU supports the notion that FDI generates beneficial impact on economic growth only if the existing human capital in a host country has reached a certain minimum threshold.

On the other hand insignificant coefficients of this term imply that the effect of FDI is not necessarily conditional on a minimum threshold of human capital. This finding is complement to the results of Borenstein (1998) and Campos-Kinoshita (2002). In that case the host country should be above the threshold of human capital necessary to adopt the advanced technology transferred by FDI. And this

${ }^{6}$ UNCTAD: World Investment Report 1999: “The impact of FDI on growth. An econometric test” p 336 
is our case about EU developed host countries.

The model's explanatory power was high $\left(\mathrm{R}^{2}\right.$-adjusted $\left.=0.51\right)$.

When the dummy variables were excluded from the pooled equation the current FDI effect on growth still remains positive and significant (Table 2). Also positive effect on growth has the current trade and past investment, while the interaction term FDI*EDU still remains insignificant. The results of the latter Table (regression results without dummies) are slightly different from that of regression with dummies.

However, we think that the results of the estimation of pooled equation with the dummies (Table 1) are the most reliable, since besides dealing with the problem of few observations, the introduction of country-dummies allows us to catch only the changes within each country, excluding the average differences among countries.

Moreover, using the Sum of Square Residuals of the above two estimations (with and without dummies), we estimate the F-statistic to check the significance of the coefficients of dummy variables. So we estimate F=(RSS'-RSS")/n$1 \div$ RSS" (nt-n-k)

Where: RSS' = OLS residuals

RSS" = Least Squares Dummy Variables Residuals

$\mathrm{n}=$ number of observations

$\mathrm{k}=$ number of explanatory variables

$\mathrm{t}=$ number of dummy variables

The estimated F-value was higher than the critical F-value at $\mathrm{a}=0.05$, so the null hypothesis about insignificant dummiesí coefficients was rejected

\section{Conclusions}

This study represents an attempt to analyze the growth-effects of FDI when other possible factors are taken into account. There is plenty of empirical evidence supporting the hypothesis that the links between FDI and growth seem to be different for countries at different stages of development. Besides, the development impact of FDI depends on the dynamics of the transfer of technology and skills by TNCs, that is: how much upgrading of local capabilities takes place over time, how far local linkages deepen, and how closely affiliates integrate themselves in the local market.

The European-Union countries are considered advanced even though not all of 
them are on the same level of development. Since they have experienced highgrowth levels, we expect that FDI should affect their growth not directly but rather indirectly by influencing other factors of growth (capital formation, trade).

By examining each country separately, FDI current inflows do not seems to affect current growth of EU countries while past level of FDI does. In general, the factors that affect growth differ across EU country-members. This could be justified by the differences in growth level between them. Concerning the role of FDI inflows on EU countries, FDI seems to affect the small economies of EU (like Ireland and Netherlands).

However, the interesting result that arises from the estimation of pooled-data equation, which is the best from technical point of view, is that the effect of FDI on the growth of EU economies is positive both directly and indirectly (through trade reinforcement).

The other interesting result is that the effect of FDI is not conditional on the human capital in developed host countries since they are above the human-capital minimum threshold, while it is conditional for the developing host economies, as comes out from many empirical studies. (similar findings are corroborated in paragraph 4 above). Since the countries of EU stand above the threshold level of human capital, the positive FDI growth is found to be independent of the level of human capital. This could be an indicator for the type of FDI inflows in advanced economies (e.g. they concentrate on technologically advanced sectors).

The negative sign of the human capital variable could imply that much of the power of foreign knowledge may come through the local base of human capital

About policy implications, those are beyond the scope of this study, where the aim was to examine empirically how FDI affects developed host economies and if the traditional theory of FDI and multinationals is in effect in those cases

However, since the traditional theory on the determinants and effects of FDI on host countries is more empirically relevant when the destination of MNEs is the developing as opposed to developed host countries, more empirical research have to be done on this last issue

\section{Acknowledgements}

The author would like to thank three anonymous referees for their insightful comments.

Also, I am indebted to my colleagues Prof. Dimitris Kirikos (Technological 
Educational Institute of Heraklion- Department of Accounting) and Prof Vangelis Tzoubelekas (University of Crete- Department of Economics) for their helpful comments.

Received 25 May 2002, Accepted 3 April 2003

\section{References}

Blomstroem M., Lipsey R. and Zejan M. (1994) What explains the growth of developing countries? Convergence of Productivity, Oxford University Press. Oxford.

Borenstein E.,De Gregorio J. and Lee J. (1998) How does Foreign Direct Investment Affect Economic Growth? Journal of International Economics, vol 45, pp 115-135.

Cambos N and Kinoshita Y. (2002) Foreign Direct Investment as Technology Transferred: some panel evidence from the transition economies, The Manchester School, vol 70 No 3.

Caves R. (1996) Multinational Enterprises and Economic Analysis, $2^{\text {nd }}$ edition, Cambridge University Press, Cambridge, MA.

Cochrane H. J. and Sbordone A. (1988) Multivariate estimates of the permanent components of GNP and stock prices, Journal of Economic Dynamics and Control, vol 12, pp 255-296.

Dunning J.H. (1981) International Production and Multinational Enterprises, George Allen \& Unwin, London.

Engle R.E and Granger C.W.J. (1987) Cointegration and error correction: Representation, Estimation and Testing, Econometrica, Vol. 55, 251-276.

Granger C.W.J. (1987) Causal Inference, in The New Palgrave: Econometrics, W. W. Norton, New York.

Granger C.W.J (1986) Developments in the study of cointegrated economic variables, Oxford Bulletin Economics and Statistics, Vol 48, 3

Hood N. Young S. (1979) The Economics if Multinational Enterprises, Longman, London $\&$ New York.

International Monetary Fund: Balance of Payments Department of FDI, Data on FDI inflows

Lipsey R. (2000) Interpreting Developed Countriesí Foreign Direct Investment, NBER Working Paper 7810

Bengoa M.-Sanchez B. (2000) Direct Investment, Economic Freedom ad Growth: New Evidence from Latin-America, NBER Working Paper(January 2000)

Osterwald-Lenum M. (1992) A note with Quantiles of the Asymptotic Distribution of the Maximum Likelihood Cointegration Rank Test Statistics, Oxford Bulletin Economics ánd Statistics, vol 54, 3

Stock J.H. and Watson M.W. (1988) Variable trends in economic time-series, Journal of Economic Perspectives, vol 2, nr 3 
UNCTAD (1999), The impact of FDI on growth: An econometric test, World Investment Report (Chapter 11, pp 329-343

Zhang K.H. (1999) FDI and economic growth: Evidence from ten East Asian Economies, Economia Internationale, Vol L11, No 4, 517-535

\section{Appendix}

\section{Description of Data}

FDI inflows series from 1970-1980 were taken from various issues of Balance of Payments of The International Monetary Fund in US dollars. From 1981-1999 FDI inflows, in euros, were taken from Eurostat through direct information from FDI department. The series in US dollars were converted into euros at official exchange rates. Then the FDI series for each country (period 1981-1999) were divided by GDP series (Gross Domestic product in current market prices in million euros. Source: European Economy, 1999).

The Annual Percentage Change of GDP at annual currency and 1995 market prices were taken from European Economy, 1999.

The Gross Fixed Capital Formation was measured at current prices, as a percentage to GDP (at market prices). Source: European Economy 1999.

The Human Capital level is measured as the ratio of the number of students in tertiary education to the number of students in total education for each country. (Since FDI in the group of countries under examination is of advanced type, the level of education that corresponds to that type is tertiary education, the most suitable to catch up the gains of advanced technology. Source: United Nations Statistical Yearbook, Human Development Report, various issues).

Economic Openness (Trade) was measured by the ratio imports + exports (of goods and services at current prices) / GDP (at market prices). Source: European Economy 2000.

The statistical software «Econometric Views» was used for the estimation and statistical tests. 